\title{
Finding What You Are Not Looking for: Strategies for Developing Novel Treatments in Psychiatry
}

\author{
Stephen M. Stahl \\ Department of Psychiatry, University of California-San Diego, San Diego, California 92037
}

\begin{abstract}
Summary: Psychopharmacological treatments in psychiatry are often surprises. Original targets frequently fail, and when successful, may only be the opening volley in a series of ever more important therapeutic applications. Drug development may begin by hypothesis-driven targeting of therapeutic indications with an agent of known and novel mechanism of action. Although this may generate a highly feasible therapeutic indication and can proceed by a well-worn regulatory pathway with known approvable endpoints, it may not only be the least innovative but also the least commercially successful strategy. Because surrogate markers of efficacy are only theoretically attractive but still largely elusive for psychiatric disorders, drug development strategies may need to proceed instead by opportunistic capturing of signals from clinical use of new agents once they enter clinical practice. Outcomes and dosing for clinical trial populations may not match those in clinical
\end{abstract}

practice, so observations from clinical practice must feed back into new clinical trials. In many ways, once efficacy is proven for the originally targeted indication, drug development begins afresh. To get to secondary stages of novel indications for psychiatric drugs and thus to maximize each drug's therapeutic potential, evidencebased prescribing is followed by prescribing-based evidence, namely feedback from clinical practice into clinical proof-of-concept studies followed by large-scale studies and new indications. In many cases, the new indications are the more important therapeutic contributions and the most successful commercial application of a drug. Here we describe this strategy of psychiatric drug development and provide numerous examples. Key Words: Indication, herapeutic target, efficacy, new claims, psychopharmacology, psychiatry.

\section{INTRODUCTION}

Drug development for psychiatric disorders has always been a mixture of science and serendipity. ${ }^{1,2}$ Many therapeutic applications in psychiatry have been surprises resulting from opportunistic exploiting of clinical observations in a hypothesis-driven drug development program. We last reviewed this topic 15 years ago in the proceedings of a British and European symposium honoring the great drug discoverer, Paul Janssen. ${ }^{1}$ It is an interesting process to see how drug development for psychiatric disorders has progressed since then, and nearly every approval listed on the numerous tables included here is the result of an innovation for a new indication that has been achieved in the past 15 years. Here we describe this process of contemporary drug development for psychiatric disorders and provide multiple examples of both successful and unsuccessful, in-

Address correspondence and reprint requests to Stephen M. Stahl, M.D., Ph.D., Neuroscience Education Institute, 5857 Owens Avenue, Suite 102, Carlsbad, CA 92008. E-mail: smstahl@neiglobal.com. novative and noninnovative approaches to the development of drugs for psychiatric disorders. ${ }^{3}$

\section{STRATEGIES FOR DEVELOPING NEW THERAPEUTICS IN PSYCHIATRY: CAN YOU GET THERE FROM HERE?}

It is well known that it can take a long while from the point in time at which any drug is discovered to the time when it is first approved for marketing. For psychiatric disorders, however, it may not be as widely appreciated that most of the truly innovative and commercially successful drug development activities actually occur after the drug is first marketed, no matter how long the time is to first marketing. Because there are often only a few years of patent life remaining when a drug is first approved, that means that there is very little time to exploit the full therapeutic potential and commercialization of drugs for psychiatric disorders. Thus, the life cycle of a psychiatric drug often extends far beyond the original patent. To fully exploit the potential of new drugs in psychiatry, it is necessary to find ways to develop new indications that are commercially viable. When this is 
TABLE 1. New Indications Approved for "Old" Drugs (after Original Patent Expiration)

\begin{tabular}{|c|c|c|}
\hline Drug & Original Indication(s) & Late Novel Indication(s) \\
\hline Clozapine & - Schizophrenia (Europe) & $\begin{array}{l}\text { - Treatment resistant schizophrenia; reduction in } \\
\text { risk of recurrent suicidal behavior in patients } \\
\text { with schizophrenia or schizoaffective disorder }\end{array}$ \\
\hline Clomipramine & - Major depression (Europe) & - Obsessive compulsive disorder \\
\hline Fluvoxamine & - Major depression (Europe) & - Obsessive compulsive disorder \\
\hline Carbamazepine & $\begin{array}{l}\text { - Seizures, pain associated } \\
\text { with trigeminal neuralgia }\end{array}$ & - Bipolar mania (extended release) \\
\hline D- and L-Amphetamine salts & - Weight loss/obesity & $\begin{array}{l}\text { - Attention deficit hyperactivity disorder in } \\
\text { children and adults (extended release) }\end{array}$ \\
\hline Bupropion & - Major depression & $\begin{array}{l}\text { - Smoking cessation (twice daily extended } \\
\text { release) }\end{array}$ \\
\hline Selegilene & - Parkinson's disease & - Major depression (transdermal) \\
\hline Sodium oxybate & - None & - Narcolepsy/cataplexy (orphan drug) \\
\hline
\end{tabular}

successful, some of the greatest therapeutic contributions are made to the field and some of the most profitable therapeutic agents are marketed. Often, this occurs almost by accident if not serendipity. Learning from the successes and failures of the past can help inform drug development strategies to optimize the potential of new therapeutics in psychiatry.

\section{DEVELOPING “OLD” DRUGS FOR NEW PSYCHIATRIC USES}

Many important new uses of psychiatric drugs have actually been discovered very late in the patent life of compounds, and sometimes even after the original compound patents for the drugs have expired. To provide at least a marginally interesting commercial incentive to develop several drugs for innovative and important new therapeutic applications in psychiatry, use patents, controlled-release patents, patent restoration, and WaxmanHatch exclusivity have all been exploited (Table 1). Without this strategy, for example, there would be no proven treatment for resistant schizophrenia, or perhaps for obsessive compulsive disorder (OCD). Thus, clozapine was initially developed for first line treatment of schizophrenia but then withdrawn from many markets due to observations of agranulocytosis. ${ }^{4}$ However, clinicians certain that clozapine was more effective than other antipsychotics encouraged the development of clozapine for the "niche" of treatment-resistant schizophrenia, with important benefits even in light of its rare toxicity, which can be handled by blood monitoring. ${ }^{5,6}$ Later, clozapine became the only drug proven to reduce suicide in schizophrenia.

Another example of novel drug development after patent expiration is the first proven treatment for OCD, clomipramine (Table 1). Both clomipramine and fluvoxamine were developed in Europe for depression but were subsequently the first agents to be developed for OCD in the U.S., but not for depression. ${ }^{4-6}$ Once the way was paved for regulatory approval for treatment of OCD by these agents, other serotonin-selective reuptake inhibitors (SSRIs) such as fluoxetine, paroxetine, and sertraline, all were also developed for OCD. Thus, late innovation led to treatment for a new disorder, and the recognition and identification of persons with this disorder skyrocketed after these approvals.

Several other examples of agents that developed new uses very late or after patent expiration are given in Table 1 , some of which also exploited extended-release technology to enhance the commercialization opportunities for these old drugs for new indications.

\section{MAXIMIZING A NEWLY APPROVED DRUG'S POTENTIAL IN PSYCHIATRIC THERAPEUTICS}

\section{Successful past examples}

Some of the best examples of "finding what you are not looking for" are the post-approval new indications for most of the major therapeutic classes of psychotropic drugs. Thus, major market expansion occurred for the SSRIs and venlafaxine for four anxiety disorders and numerous subtypes of depression (Table 2). The antidepressant duloxetine became the first drug ever approved for the treatment of neuropathic pain in the U.S. ${ }^{5,6}$ The commercial success of many anticonvulsants, especially divalproex, is due much more to the secondary approval for treatment of bipolar disorder than to the primary approval for seizures. Atypical antipsychotics have greatly expanded their therapeutic and market potential by gaining a secondary claim in bipolar disorder, where there are more patients than schizophrenia, the primary claim. Who would have predicted at the time of first approval that an antidepressant would be useful for pain, an anticonvulsant for mania, or even antidepressants for so many anxiety disorders and antipsychotics for mood stabilization of nonpsychotic mania and depression? These new indications arose as much from empiric ob- 
TABLE 2. New Indications Approved for "New" Drugs (within Original Patent Life)

\begin{tabular}{|c|c|c|}
\hline Drug & Original/First Indication & Second/New Indication(s) \\
\hline Alprazolam & $\begin{array}{l}\text { - Generalized anxiety } \\
\text { disorder }\end{array}$ & - Panic disorder \\
\hline $\begin{array}{l}\text { SSRIs (serotonin-selective reuptake } \\
\text { inhibitors; fluoxetine, sertraline, } \\
\text { paroxetine, escitalopram) }\end{array}$ & - Major depression & $\begin{array}{l}\text { - Obsessive compulsive disorder } \\
\text { - Panic disorder } \\
\text { - Social anxiety disorder } \\
\text { - Post traumatic stress disorder } \\
\text { - Premenstrual dysphoric disorder } \\
\text { - Bulimia nervosa } \\
\text { - Bipolar depression (fluoxetine in combination } \\
\text { - Pith olanzapine) } \\
\text { - Pediatric depression (fluoxetine) }\end{array}$ \\
\hline Venlafaxine & - Major depression & $\begin{array}{l}\text { - Generalized anxiety disorder } \\
\text { - Social anxiety disorder }\end{array}$ \\
\hline Duloxetine & - Major depression & $\begin{array}{l}\text { - Panic disorder } \\
\text { - Neuropathic pain (diabetic peripheral } \\
\text { neuropathy) }\end{array}$ \\
\hline Divalproex & - Seizures & - Bipolar disorder; migraine \\
\hline Lamotrigine & - Seizures & - Bipolar maintenance \\
\hline Modafinil & - Narcolepsy & $\begin{array}{l}\text { - Obstructive sleep apnea } \\
\text { - Shift work sleep disorder }\end{array}$ \\
\hline Ropinirole & - Parkinson's disease & - Restless legs syndrome \\
\hline $\begin{array}{l}\text { Atypical antipsychotics } \\
\text { (risperidone, olanzapine, } \\
\text { quetiapine, ziprasidone, } \\
\text { aripiprazole) }\end{array}$ & - Schizophrenia & $\begin{array}{l}\text { - Bipolar mania } \\
\text { - Bipolar depression (fluoxetine in combination } \\
\text { with olanzapine) }\end{array}$ \\
\hline
\end{tabular}

servations of clinical use of these agents, followed by proof-of-concept trials in a new disorder, culminating in trials to win formal approval for a new indication. Both unmet therapeutic needs in psychiatry and significantly enhanced commercial success were byproducts of astute targeting of post-approval new indications for each of these agents in Table 2.

\section{Potential for currently marketed psychiatric drugs}

The strategy of generating multiple new indications as soon as possible after winning initial approval is continuing apace for many approved psychotropic drugs that are still on patent (Table 3). Thus, expanded claims for the atypical antipsychotics may result in approvals specifically for the cognitive symptoms and for the negative symptoms of schizophrenia. ${ }^{7,8}$ Pregabalin's manufacturer will try for approval for the treatment of anxiety disorders, and the new hypnotic eszopiclone may become an approved adjunctive agent for the treatment and prevention of relapse in major depression. A controlled release formulation of the antihypertensive agent guanfacine may become approved for the treatment of attention deficit disorder. All of these agents (Table 3) are taking a page out of the chapter of the book written by the drugs in Table 2 and attempting to expand indications to new areas based in part on the actions of drugs with similar mechanisms, ${ }^{9,10}$ and in part upon the actions of drugs observed in clinical practice. ${ }^{11}$

\section{ANTICIPATING NOVEL SECONDARY INDICATIONS FOR PSYCHIATRIC DRUGS STILL IN DEVELOPMENT}

It should not be surprising, given the success of old drugs and currently approved drugs for psychiatric disorders, that drugs yet to win their first approval are already planning for secondary approvals as soon as possible after initial marketing. For antidepressants, this is especially important to their commercialization because approval merely for major depression may relegate them to second line use given the increasing availability of many generic alternatives now and in coming years. Thus, antidepressants for premature ejaculation, hot flushes, fibromyalgia, and various functional somatic syndromes may have greater commercial potential than for major depression alone (Table 4).

\section{CAN ACTIVE ENANTIOMERS, EXTENDED- RELEASE FORMULATIONS, AND ACTIVE METABOLITES BE EXPLOITED FOR TRULY INNOVATIVE AND COMMERCIALLY SUCCESSFUL PSYCHIATRIC THERAPEUTICS?}

Active enantiomers can provide a strategy to commercialize novel psychiatric indications of older drugs (Table 5). ${ }^{12}$ Probably the most successful commercial ex- 
TABLE 3. Pending New Indications in Development for Approved Drugs

\begin{tabular}{|c|c|c|}
\hline Drug & Approved for & Potential New Indications \\
\hline $\begin{array}{l}\text { Atypical antipsychotics } \\
\text { (resperidone, olanzapine, } \\
\text { quetiapine, ziprasidone, } \\
\text { aripiprazole }\end{array}$ & $\begin{array}{l}\text { - Schizophrenia } \\
\text { - Bipolar disorder }\end{array}$ & $\begin{array}{l}\text { - Cognitive symptoms of schizophrenia } \\
\text { - Negative symptoms of schizophrenia } \\
\text { - Major depression } \\
\text { - Treatment resistant depression } \\
\text { - Borderline personality disorder } \\
\text { - Stimulant abuse }\end{array}$ \\
\hline Guanfacine & - Hypertension & - Attention deficit disorder (extended release) \\
\hline Modafinil & $\begin{array}{l}\text { - Narcolepsy } \\
\text { - Sleep apnea } \\
\text { - Shift work sleep disorder }\end{array}$ & - Attention deficit disorder \\
\hline Pregabalin & - Neuropathic pain & $\begin{array}{l}\text { - Anxiety disorders } \\
\text { - Fibromyalgia }\end{array}$ \\
\hline Pramipaxole, dopamine agonists & - Parkinson's disease & $\begin{array}{l}\text { - Restless legs syndrome } \\
\text { - Bipolar depression }\end{array}$ \\
\hline Eszopiclone & - Insomnia & - Adjunctive treatment of major depression \\
\hline
\end{tabular}

ample of this is the active enantiomer of citalopram (escitalpram). It may provide more selectivity of action and better tolerability, but some still question how much of an innovation this represents. Probably the most clever use of enantiomers is to take a product never developed in the U.S. as the racemate and develop its active enantiomer while simultaneously earning a novel claim. That example is eszopiclone, the first agent approved without short-term dosing limits for insomnia.,

Extended-release formulations have frequently been debated as to whether they are incremental innovations or patent extension gimmicks. ${ }^{13}$ They can be both (Table 6). Some of the most innovative uses of extended-release technology may be transdermal delivery of selegiline (Table 1) to add major depression as a claim to a drug approved in the oral dosage form for Parkinson's dis- ease. ${ }^{14}$ Some extended-release technologies convert short-acting drugs to once a day administration while often improving tolerability and becoming commercial successes (Table 6; e.g., Effexor XR, controlled-release stimulants; Wellbutrin XL, Depakote ER), whereas others may not add much value to the original compound and are not yet commercially successful (e.g., Paxil CR, Xanax XR, Prozac weekly, Ambien CR).

Finally, active metabolites may or may not prove to be an innovation and commercial success. Three examples currently in clinical development are listed in Table 7. Whereas it may be difficult to see the added value of desmethylvenlafaxine over venlafaxine, radafaxine may have greater potency for the noradrenergic transporter compared to bupropion, and the oxcarbazepine metabolite licarbazepine may give the chance to develop this

TABLE 4. Pending New and Novel Indications for Drugs Still in Development

\begin{tabular}{|c|c|c|}
\hline Drug & Ordinarily Targeted Indication & Novel Indication \\
\hline $\begin{array}{l}\text { SSRI-serotonin selective reuptake } \\
\text { inhibitor (dapoxetine) }\end{array}$ & - Major depression; anxiety disorders & - Premature ejaculation \\
\hline $\begin{array}{l}\text { SNRI-serotonin norepineprhine } \\
\text { reuptake inhibitor (desmethyl- } \\
\text { venlafaxine; milnacipran) }\end{array}$ & - Major depression; anxiety disorders & - Hot flushes; fibromyalgia \\
\hline $\begin{array}{l}\text { Varenicline (alpha } 4 \text { beta } 2 \\
\text { nicotinic partial agonist) }\end{array}$ & $\begin{array}{l}\text { - Smoking cessation/nicotine } \\
\text { dependence }\end{array}$ & $\begin{array}{l}\text { - Nicotine dependence in comorbid } \\
\text { psychiatric disorders }\end{array}$ \\
\hline $\begin{array}{l}\text { Radafaxine (norepinephrine and } \\
\text { dopamine reuptake inhibitor) }\end{array}$ & - Major depression & $\begin{array}{l}\text { - Attention deficit disorder } \\
\text { - Weight loss/obesity }\end{array}$ \\
\hline Various antidepressants & - Major depression & $\begin{array}{l}\text { - Functional somatic syndromes (e.g. } \\
\text { fibromyalgia, irritable bowel } \\
\text { syndrome, sleep apnea, tinnitus, } \\
\text { chronic fatigue) }\end{array}$ \\
\hline $\begin{array}{l}\text { Remonibant (cannabinoid } 1 \\
\text { antagonist) }\end{array}$ & - Metabolic syndrome & $\begin{array}{l}\text { - Weight loss/obesity } \\
\text { - Smoking cessation } \\
\text { - Schizophrenia }\end{array}$ \\
\hline Sodium oxybate & - Narcolepsy/cataplexy & - Fibromyalgia \\
\hline Indiplon & - Chronic insomnia & $\begin{array}{l}\text { - Adjunctive treatment of major } \\
\text { depression }\end{array}$ \\
\hline
\end{tabular}


TABLE 5. Gimmicks or Incremental Innovations? Effective and Ineffective Uses of Active Enantiomers

\begin{tabular}{lll}
\hline Original Drug & \multicolumn{1}{c}{ Strategy } & \multicolumn{1}{c}{ Comment } \\
\hline Citalopram & $\bullet$ Active enantiomer (escitalopram) & $\bullet$ Commercially successful \\
Zopiclone & $\bullet$ Active enantiomer (eszopiclone) & $\bullet$ Innovation \\
Modafinil & $\bullet$ Active enantiomer (armodafinil) & $\bullet$ Novel claim for chronic insomnia \\
Methylphenidate & $\bullet$ Active enantiomer (dexmethylphenidate) & $\bullet$ Longer half life \\
\end{tabular}

compound for bipolar disorder when the parent compound was not exploited for this purpose.

\section{MISSED OPPORTUNITIES}

It may be useful to look back upon drugs with expired patents to see if there are any missed opportunities, and then to see if there is any route to providing an incentive to commercialize these agents for new uses (Table 8). Perhaps the greatest missed opportunity from a commercial value point of view is the lack of development of oxcarbazepine for bipolar disorder. Anticonvulsants approved for use in bipolar disorder have considerably greater sales for that indication than for seizures, and oxcarbazepine, which shares a common mechanism of action with carbamazepine proven to work in bipolar disorder, is highly likely to be effective in this condition. It is not clear why this somewhat obvious candidate was never fully developed to its potential.

Many other examples abound and some are listed in Table 8. Knowing what we know now about psychiatric disorders, if there were patent coverage on the agents in this table, there may well be current drug development activities for the suggested potential claims. These agents have far more value from the point of view of meeting

TABLE 6. Gimmicks or Incremental Innovations? Effective and Ineffective Uses of Extended Release Formulations

\begin{tabular}{|c|c|c|}
\hline Original Drug & Strategy & Comment \\
\hline Paroxetine & Extended release (Paxil CR) & $\begin{array}{l}\text { - ? Innovation } \\
\text { - Not commercially successful }\end{array}$ \\
\hline Bupropion & Extended release (Wellbutrin XL) & $\begin{array}{l}\text { - Converting from twice daily to once daily } \\
\text { considered a real improvement } \\
\text { - Commercially successful }\end{array}$ \\
\hline Venlafaxine & Extended release (Effexor XR) & $\begin{array}{l}\text { - Once daily and reduced nausea } \\
\text { - Commercially successful }\end{array}$ \\
\hline Fluoxetine & Extended release (Prozac weekly) & - ? Innovation \\
\hline Divalproex & Extended release (Depakote ER) & $\begin{array}{l}\text { - Once daily } \\
\text { - Fewer peak dose side effects } \\
\text { - Commercially successful }\end{array}$ \\
\hline Alprazolam & Extended release (Xanax XR) & $\begin{array}{l}\text { - ? Innovation } \\
\text { - Once or twice daily } \\
\text { - Not commercially successful }\end{array}$ \\
\hline Risperidone & $\begin{array}{l}\text { Biweekly depot injection (Risperdal } \\
\text { Consta) }\end{array}$ & $\begin{array}{l}\text { - Useful for compliance } \\
\text { - Limited commercial success }\end{array}$ \\
\hline Zolpidem & Extended release (Ambien CR) & - ? Innovation \\
\hline Indiplon & Modified release (indiplon MR) & $\begin{array}{l}\text { - Immediate release for short duration effects } \\
\text { when desired (in development) } \\
\text { - Modified release to extend duration and } \\
\text { could improve efficacy (in development) }\end{array}$ \\
\hline Zaleplon & Extended release & - Could improve efficacy (in development) \\
\hline \multirow{3}{*}{$\begin{array}{l}\text { Stimulants } \\
\text { D and L-Amphetamine salts } \\
\text { Methylphenidate }\end{array}$} & Extended release & - Eliminated need for lunchtime dosing \\
\hline & Adderal XR & - Commercially successful \\
\hline & $\begin{array}{l}\text { Concerta; Ritalin LA } \\
\text { Metadate CD }\end{array}$ & \\
\hline Methylphenidate & Transdermal patch & •? Innovation (in development) \\
\hline Methylphenidate & $\begin{array}{l}\text { Active enantiomer (dexmethylphenidate) } \\
\text { with extended release }\end{array}$ & - Eliminated need for lunchtime dosing \\
\hline Lamotrigine & Once daily extended release & - ? Innovation \\
\hline Memantine & Once daily extended release & - ? Innovation \\
\hline
\end{tabular}


TABLE 7. Gimmicks or Incremental Innovations? Effective and Ineffective Uses of Active Metabolites

\begin{tabular}{|c|c|c|}
\hline Original Drug & Strategy & Comment \\
\hline Venlafaxine & $\begin{array}{l}\text { - Active metabolite } \\
\text { - Desmethylvenlafaxine }\end{array}$ & •? Innovation \\
\hline Bupropion & $\begin{array}{l}\text { - Active enantiomer of active metabolite } \\
\text { - +6-Hydroxybupropion or radafaxine }\end{array}$ & $\begin{array}{l}\text { - Enhanced noradrenergic action } \\
\text { compared with bupropion }\end{array}$ \\
\hline Oxcarbazepine & $\begin{array}{l}\text { - Active enantiomer of active metabolite } \\
\text { - Monohydroxy deriviative } \\
\text { - S-licarbazepine }\end{array}$ & - Chance to develop for bipolar disorder \\
\hline
\end{tabular}

unmet therapeutic needs than in providing any commercial opportunity to do so, which is regrettable and speaks to the necessity of starting the development of new indications as early as foreseeable in the patent life of a compound.

\section{OFF LABEL USE WITHOUT FORMAL DRUG DEVELOPMENT}

Sometimes, you get lucky. There are several examples of such obvious utility of some compounds for some indications, that there is great acceptance for use "off label" without formal drug development to attain a secondary claim (Table 9). This includes clonazepam for panic, which was the most widely used antipanic agent in psychiatry and did not receive a claim until it was off patent. It also includes trazodone, still the most widely prescribed hypnotic without any claim other than major depression. Zolpidem never underwent the studies that were recently completed on eszopiclone, to remove limits on duration of treatment for chronic insomnia but was nevertheless used chronically without the claim. Gabapentin, now off patent, is an example of both the best and the worst of off-label uses. It never underwent the studies for chronic pain now completed for its sister compound with an identical mechanism of action, pregabalin and still on patent, but it has attained widespread acceptance

TABLE 8. Missed U.S. Opportunities

\begin{tabular}{|c|c|}
\hline Drug & Potential Claim \\
\hline Oxcarbazepine & - Bipolar disorder; neuropathic pain \\
\hline Amantadine & - Fatigue; Alzheimer's dementia \\
\hline Riluzole & - Bipolar depression \\
\hline Divalproex & - Adjunctive treatment of schizophrenia \\
\hline Modafinil & - Attention deficit disorder (too late?) \\
\hline Bupropion & - Attention deficit disorder \\
\hline Lithium & $\begin{array}{l}\text { - Reduction of suicide; } \\
\text { - Vascular/cluster headache }\end{array}$ \\
\hline Mirtazapine & - Anxiety disorders; insomnia \\
\hline Zaleplon & - Chronic insomnia treatment \\
\hline Venlafaxine & $\begin{array}{l}\text { - Neuropathic pain; } \\
\text { - Fibromyalgia }\end{array}$ \\
\hline Lamotrigine & - Neuropathic pain \\
\hline Clomipramine & - Cataplexy \\
\hline $\begin{array}{l}\text { Cholinesterase inhibitors donepezil, } \\
\text { rivastigmine, galantamine }\end{array}$ & $\begin{array}{l}\text { - Vascular dementia; } \\
\text { - Mild cognitive impairment }\end{array}$ \\
\hline Atypical antipsychotics & $\begin{array}{l}\text { - Children } \\
\text { - Behavioral disturbances in dementia }\end{array}$ \\
\hline Milnacipran & - Major depression \\
\hline Tiagabine & $\begin{array}{l}\text { - Anxiety disorder; } \\
\text { - Chronic pain }\end{array}$ \\
\hline Topiramate & - Eating disorders; alcoholism \\
\hline Duloxetine & - Stress urinary incontinence \\
\hline Reboxetine & - Major depression; attention deficit disorder; neuropathic pain \\
\hline Citalopram & - Anxiety disoders \\
\hline Loxapine & - At low doses, an atypical antipsychotic \\
\hline Mazindol & - Stimulant abuse; geriatric depression \\
\hline Amisulpride & - Schizophrenia, mania \\
\hline Quetiapine & $\begin{array}{l}\text { - Behavior disturbances in Lewy Body dementia and Parkinson dementia; } \\
\text { - Psychosis in levodopa treatment of Parkinson's disease }\end{array}$ \\
\hline
\end{tabular}


TABLE 9. Successful Off-Label Use without Claims

\begin{tabular}{ll}
\hline Clonazepam & $\bullet$ Panic \\
Trazadone & $\bullet$ Insomnia \\
Gabapentin & $\bullet$ Neuropathic pain \\
& $\bullet$ Anxiety \\
& $\bullet$ Bipolar disorder \\
Zolpidem & $\bullet$ Miscellaneous psychiatric disorders \\
\hline
\end{tabular}

for this use. Gabapentin was also widely touted as being effective for virtually any psychiatric disorder, including bipolar disorder where there is scant convincing evidence, and prescribed without justification or evidence for many patients.

\section{SUMMARY}

Most clinical innovation in therapeutics for psychiatry comes after initial marketing of compounds for different indications. To get the most out of a compound's commercial potential as well as its therapeutic potential, the strategy is to "find what you are not looking for," namely by discovering unforeseen and unpredicted therapeutic applications of compounds in psychiatry.

\section{REFERENCES}

1. Stahl SM. Needs and opportunities for innovation in psychopharmacology. J Royal Soc Med 80:413-417, 1987.

2. Stahl SM. Does evidence from clinical trials in psychopharmacology apply in clinical practice? J Clin Psychiatry 62:6-7, 2001.

3. Kapur S, Agid O, Mizrahi R, Li M. How antipsychotics workfrom receptors to reality. NeuroRx 3:10-21, 2006.

4. Stahl SM. Essential psychopharmacology. 2nd ed. New York: Cambridge University Press, 2000.

5. Stahl SM. Essential psychopharmacology: the prescriber's guide. New York: Cambridge University Press, 2005.

6. Physician's desk reference, 2005.

7. Blasi G, Bertolino A. Imaging genomics and response to treatment with antipsychotics in schizophrenia. NeuroRx $3: 117-130$, 2006.

8. Apud JA. The pharmocogenomics of the dorsolateral prefrontal cortex: a new tool for the development of "target-oriented" cognitive enhancing drugs. NeuroRx 3:106-116, 2006.

9. Simon AB, Gorman JM. Advances in the treatment of anxiety: targeting glutamate. NeuroRx 3:57-68, 2006.

10. Carlson PJ, Singh JB, Zarate CA Jr, Drevets WC, Manji HK Neural circuitry and neuroplasticity in mood disorders: insights for novel therapeutic targets. NeuroRx 3:22-41, 2006.

11. Pittenger C, Krystal JH, Coric V. Glutamate-modulating drugs as novel pharmacotherapeutic agents in the treatment of obsessivecompulsive disorder. NeuroRx 3:69-81, 2006.

12. Stahl SM. At long last, long-lasting psychiatric medications: an overview of controlled-release technologies. J Clin Psychiatry 64: 355-356, 2002

13. Stahl SM. Mirror, mirror on the wall, which enantiomer is fairest of them all? J Clin Psychiatry 63:56-57, 2002.

14. Holzheimer PE III, Nemeroff CB. Advances in the treatment of depression. NeuroRx 3:42-56, 2006. 